\title{
Wydajność fiskalna i wykorzystanie władztwa podatkowego przez gminy w podatku rolnym
}

Fiscal efficiency and the use of tax power by municipalities in agricultural tax

\section{Wprowadzenie}

Kwestie dotyczące dochodów gmin i wykorzystania podatków lokalnych, na których konstrukcję gminy mogą oddziaływać, a więc m.in. podatku rolnego, są bardzo istotne i stanowią przedmiot nieustannego zainteresowania zarówno przedstawicieli nauki, jak i samorządowców. Problemem tym zajmowano się, rozpatrując go z różnych punktów widzenia, oceniając właściwość konstrukcji podatku rolnego oraz jego wydajność fiskalną (m.in. L. Etel, S. Presnarowicz, R. Dziemianowicz, P. Felis, R. Przygodzka), badając wykorzystanie władztwa podatkowego przez gminy i rolę tej daniny dla zapewnienia im samodzielności (m.in. B. Filipiak, J. Kulicki, R. Przygodzka, J. Śmiechowicz, P. Kozak), a wreszcie proponując gruntowną reformę opodatkowania rolnictwa (E. Kornberger-Sokołowska, A. Pomorska i in., K. Wójtowicz). Badania dotyczące podatku rolnego powinny być kontynuowane nie tylko dlatego, że stanowi on ważne źródło dochodów podatkowych, zwłaszcza gmin wiejskich i miejsko-wiejskich. Przemawia za tym również fakt, że warunki, w jakich decydowano o jego budowie, znacznie różniły się od obecnych i konstrukcję tego podatku można dziś uznać za anachroniczną, niesprawiedliwą, niedostosowaną do obecnych warunków społeczno-ekonomicznych panujących w Polsce i standardów obowiązujących w państwach Unii Europejskiej (Dziemianowicz, 2007, s. 191). Potrzebę zmian $\mathrm{w}$ tym zakresie dostrzegają nawet rolnicy, choć ich wizja opodatkowania rolnictwa odbiega od postulatów strony samorządowej i przedstawicieli nauki (zob. Kisiel \& Idzikowska, 2014, s. 64-78). 
Celem ogólnym opracowania jest zbadanie, jak zmienia się rola podatku rolnego w tworzeniu dochodów gmin i prowadzona przez nie polityka podatkowa oraz jakie są jej konsekwencje dla budżetów. Za cel szczegółowy przyjęto zbadanie zróżnicowania wydajności fiskalnej i wykorzystania władztwa podatkowego przez różne typy gmin w województwie lubelskim. W artykule weryfikacji poddano dwie hipotezy. Pierwsza - wydajność fiskalna podatku rolnego ulega redukcji, do czego przyczynia się łagodna polityka podatkowa gmin. Druga - podatek rolny jest wydajną fiskalnie daniną tylko w gminach wiejskich. W badaniach uwzględniono długi okres, tj. lata 2003-2018, by lepiej uchwycić zmieniające się tendencje. W pierwszej części badań, dotyczącej ogólnie oceny wydajności fiskalnej podatku rolnego i skutków polityki podatkowej gmin, uwzględniono dane zbiorcze charakteryzujące wszystkie gminy w kraju (bez miast na prawach powiatu). W drugiej części skupiono się natomiast na jednostkach położonych w województwie lubelskim, czyli na gminach wiejskich, miejskich oraz miejsko-wiejskich, i ograniczono do analizy danych z 2018 r. Oparto się przy tym na danych zgromadzonych w bazie Głównego Urzędu Statystycznego (BDL), danych zawartych w sprawozdaniach Rb-27S, udostępnionych na stronie internetowej Regionalnej Izby Obrachunkowej w Lublinie, oraz danych zawartych w Sprawozdaniach z działalności regionalnych izb obrachunkowych i wykonania budżetu przez jednostki samorządu terytorialnego za lata 2003-2018. Przygotowanie artykułu wymagało zastosowania metody analizy porównawczej, prostej analizy statystycznej danych oraz metody dedukcyjnej.

\section{Charakterystyka podatku rolnego}

Obowiązujący w Polsce podatek rolny, pobierany na podstawie ustawy z dn. 15 listopada 1984 r. o podatku rolnym (Dz.U. z 2019 r. poz. 1256 z późn. zm.), jest obciążeniem o charakterze przychodowo-majątkowym. W całości zalicza się do dochodów własnych gmin i stanowi jedno z ważniejszych podatkowych źródeł ich zasilania finansowego. Do zasadniczych cech tej daniny należy prosta konstrukcja oraz bardzo silny związek z terytorium danego samorządu i zadaniami realizowanymi przez władze lokalne (Kowalski \& Wigiera, 2012, s. 152). Przyjęty w Polsce system opodatkowania rolnictwa odbiega od rozwiązań obowiązujących w państwach o rozwiniętych gospodarkach (Dziemianowicz, 2007). W krajach Unii Europejskiej dochody, w zależności od formy organizacyjno-prawnej, w jakiej prowadzona jest działalność rolnicza, obciążone są podatkiem od dochodów osobistych lub podatkiem korporacyjnym (Felis, 2015, s. 24), zaś na ich wyso- 
kość wpływają nie tylko skale podatkowe, ale także zasady ustalenia podstawy opodatkowania (Eurostat, 2013; OECD, 2005; van der Veen, van der Meulen, van Bommel \& Doorneweert, 2007). W Polsce rolnicy, poza prowadzącymi działy specjalne produkcji rolnej, nie płacą podatku dochodowego, ponieważ z jego zakresu przedmiotowego wyłączono dochody uzyskiwane z produkcji rolnej, podatek rolny jest więc najważniejszą daniną obciążającą rolnictwo w Polsce.

Podatnikami podatku rolnego są osoby fizyczne, osoby prawne oraz jednostki organizacyjne, w tym spółki, nieposiadające osobowości prawnej, będące właścicielami gruntów, posiadaczami samoistnymi gruntów, użytkownikami wieczystymi gruntów lub też posiadaczami zależnymi gruntów stanowiących własność Skarbu Państwa lub jednostki samorządu terytorialnego. Zakres przedmiotowy podatku rolnego od 2003 r. obejmuje grunty sklasyfikowane w ewidencji gruntów i budynków jako użytki rolne lub jako grunty zadrzewione i zakrzewione na użytkach rolnych, z wyjątkiem gruntów zajętych na prowadzenie działalności gospodarczej innej niż działalność rolnicza, przy czym za działalność taką uznaje się produkcję roślinną i zwierzęcą, w tym również produkcję materiału siewnego, szkółkarskiego, hodowlanego oraz reprodukcyjnego, produkcję warzywniczą, roślin ozdobnych, grzybów uprawnych, a także sadownictwo, hodowlę i produkcję materiału zarodowego zwierząt, ptactwa i owadów użytkowych, produkcję zwierzęcą typu przemysłowego fermowego oraz chów i hodowlę ryb (Ustawa $\mathrm{z}$ dn. 15 listopada 1984 r. o podatku rolnym, art. 2 ust. 2).

Cechą polskiego podatku rolnego jest ścisły związek jego wysokości z położeniem gruntu. Podstawą opodatkowania w przypadku gospodarstwa rolnego jest liczba hektarów przeliczeniowych, a w odniesieniu do gruntów nietworzących takiego gospodarstwa - powierzchnia wyrażona w hektarach fizycznych wynikająca $z$ ewidencji gruntów i budynków. Zgodnie z definicją ustawową, gospodarstwem rolnym są grunty o łącznej powierzchni przekraczającej 1 ha lub 1 ha przeliczeniowy (Ustawa $\mathrm{z}$ dn. 15 listopada 1984 r. o podatku rolnym, art. 2 ust. 1). Ustalając liczbę hektarów przeliczeniowych, uwzględnia się faktyczną powierzchnię gospodarstwa, rodzaj i klasę użytków rolnych wynikającą z ewidencji gruntów oraz zaliczenie do jednego z czterech okręgów podatkowych. W ten sposób powiązano wysokość podatku z potencjalnymi możliwościami produkcyjnymi gospodarstw, wpływającymi na poziom uzyskiwanych przez podatników dochodów. W podatku wykorzystywany jest jeden typ stawki, tj. stawka kwotowa, przy czym jej wysokość jest zróżnicowana i zależy od tego, czy przedmiotem opodatkowania są grunty wchodzące w skład gospodarstwa rolnego, czy też pozostałe grunty. Stawka podatku powiązana jest z ceną kwintala żyta, a więc tylko jednego produktu, charakteryzującego się niezbyt wysokim oraz 
dodatkowo malejącym udziałem w produkcji rolnej w Polsce'. Takie rozwiązanie oceniane jest krytycznie w literaturze przedmiotu (zob. Dziemianowicz, 2007, s. 317; Etel, 2003, s. 342).

W podatku rolnym ustawodawca przewidział bardzo szeroki system ulg oraz zwolnień podatkowych, wprowadzając je ze zarówno ze względów ekonomicznych, jak i społecznych. Wśród nich znajdują się preferencje o charakterze podmiotowym oraz przedmiotowym, stosowane z urzędu lub na wniosek podatnika. Główne zwolnienia obejmują: zwolnienie użytków rolnych słabej jakości tj. V, VI klasy; trwające pięć lat zwolnienie gruntów przeznaczonych na utworzenie nowego gospodarstwa rolnego lub powiększenie istniejącego, ale maksymalnie do powierzchni nieprzekraczającej 100 ha oraz gruntów powstałych z zagospodarowania nieużytków (w następnych dwóch latach podatnikom przysługuje jeszcze ulga pozwalająca na redukcję podatku najpierw 0 75\%, a następnie 0 50\%); zwolnienie użytków rolnych objętych melioracją w roku, w którym doszło do zniszczenia upraw z powodu robót drenarskich. Katalog ulg ustawowych przewiduje redukcję podatku w związku z prowadzeniem gospodarstwa w trudnych warunkach, czyli górskich lub podgórskich, realizacją inwestycji oraz z tytułu klęski żywiołowej poprzez zaniechanie ustalenia lub poboru podatku.

Podatek rolny jest płacony w czterech ratach proporcjonalnych do czasu trwania obowiązku podatkowego w terminach do 15 marca, 15 maja, 15 września i 15 listopada roku podatkowego na podstawie decyzji organu podatkowego w przypadku osób fizycznych, a w przypadku osób prawnych - na podstawie deklaracji składanych przez nie do 15 stycznia roku podatkowego (Ustawa z dn. 15 listopada 1984 r. o podatku rolnym, art. 6a).

\section{Władztwo podatkowe gmin w kwestii podatku rolnego}

Zgodnie z Europejską Kartą Samorządu Lokalnego przynajmniej część dochodów jednostek samorządu terytorialnego powinna pochodzić z podatków i opłat lokalnych, których wysokość mają one prawo ustalać w zakresie wyznaczonym przez przepisy rangi ustawy (Europejska Karta Samorządu Lokalnego sporządzona w Strasburgu dnia 15 października 1985 r.), co oznacza, że winny one dysponować władztwem podatkowym. W Polsce podstawą uprawnień samorządu do ustalania

1 W okresie 2005-2018 udział zasiewów żytem do ogólnej powierzchni zasiewów uległ redukcji z 17,2\% do 7,4\%. Zob. GUS, 2019. 
wysokości podatków jest art. 168 Konstytucji RP (Konstytucja Rzeczpospolitej Polskie z dn. 2 kwietnia 1997 r.), z tym że zgodnie z ustawą o dochodach jednostek samorządu terytorialnego (Ustawa $\mathrm{z}$ dn. 13 listopada 2003 r. o dochodach jednostek samorządu terytorialnego) możliwość taka przysługuje wyłącznie jednostkom szczebla podstawowego. Standardy wynikające $\mathrm{z}$ tych regulacji są więc realizowane tylko w ograniczonym stopniu (zob. Ofiarski, 2016, s. 267). Co więcej, autonomia podatkowa gmin jest zawężona do tworzenia prawa lokalnego, adresowanego do raczej wąskiej grupy odbiorców, oraz do stosowania prawa przez organy wykonawcze gmin (wójtów, burmistrzów i prezydentów), które wydają decyzje w indywidualnych sprawach. Granice samodzielności gmin na tym polu wyznacza art. 217 Konstytucji RP, zastrzegając formę ustawy dla nakładania podatków i określania wszystkich istotnych elementów podatku. Zatem władztwo podatkowe gmin przejawia się jedynie w kształtowaniu (modelowaniu) obciążeń podatkowych, a nie stanowieniu podatków (Kulicki, 2010, s. 10-11) i obejmuje uprawnienia o szerszym i węższym zakresie oddziaływania. Do pierwszej kategorii zalicza się określanie stawek podatkowych, ale tylko w granicach określonych w ustawie, stosowanie ulg oraz zwolnien przedmiotowych. Druga kategoria obejmuje udzielane raczej wyjątkowo i skierowane jedynie do zainteresowanych podmiotów preferencje, takie jak umarzanie i rozkładanie należności podatkowych na raty oraz odraczanie terminów płatności. Stanowią one instrument pomocy publicznej, stosowanej ze względu na ważny interes podatnika lub ważny interes publiczny (Filipiak, 2016, s. 4). Podejmując powyższe działania, władze gmin wykonują swoje administracyjne kompetencje, ale równocześnie mogą wykorzystywać je do prowadzenia przemyślanej gminnej polityki podatkowej. Pamiętać jednak należy, że władztwo podatkowe przysługuje gminom wyłącznie w odniesieniu do tych podatków, które są pobierane przez samorządowe organy podatkowe, a więc do: rolnego, leśnego, od nieruchomości i od środków transportowych.

Uprawnienia, jakie gminy posiadają $\mathrm{w}$ odniesieniu do podatku rolnego, określane są jako pełne władztwo podatkowe, a więc władztwo czynne w sensie szerokim (Filipiak, 2015, s. 223). Niewątpliwie najistotniejszym uprawnieniem gmin w obszarze kształtowania podatków lokalnych jest prawo do określania wysokości stawek, które w podatku rolnym ustalane są pośrednio - poprzez wykorzystanie tzw. stabilizatorów, tj. obniżenie ceny skupu żyta (Filipiak, 2015, s. 224). Swoboda władz gminnych w tym obszarze jest jednak ograniczona. Organy uchwałodawcze mogą ewentualnie obniżyć stawkę maksymalną, ustalaną na podstawie średniej ceny skupu żyta ogłaszanej w komunikacie Prezesa Głównego Urzędu Statystycznego, zamieszczanym w Dzienniku Urzędowym 
Rzeczypospolitej Polskiej „Monitor Polski”, w terminie do dnia 20 października roku poprzedzającego rok podatkowy. Nie wolno im jednak przyjąć stawki o zł (Etel, Presnarowicz \& Dudar, 2008, s. 191), co oznaczałoby w rzeczywistości zwolnienie od podatku: tego rodzaju kompetencji rady gmin nie posiadają.

Poza wpływem na wysokość stawki podatkowej obowiązującej w gminie, jej rada ma również prawo stosowania, zgodnie z przepisami ustawy, zwolnień i ulg podatkowych - albo w wyniku decyzji urzędu, albo na wniosek podatnika. Przykładem ulgi na wniosek podatnika jest zaniechanie ustalenia bądź obniżenie poboru podatku w całości lub części w sytuacji wystąpienia klęski żywiołowej. Gmina może także określić tryb i warunki zwolnienia w stosunku do osób będących podatnikami podatku rolnego od użytków rolnych, na których zaprzestano produkcji rolnej, ale maksymalny okres jego przyznania wynosi trzy lata. Kolejną kompetencją rady gminy jest uprawnienie do kształtowania podstawy opodatkowania w określonym zakresie (Ustawa z dn. 15 listopada 1984 r. o podatku rolnym, art. 5 ust. 3), poprzez przekwalifikowanie poszczególnych użytków rolnych (Przygodzka, 2014, s. 336). Uczynić to jednak może po zasięgnięciu opinii izby rolniczej, a działanie takie musi mieć szczególne uzasadnienie gospodarcze. W efekcie zmiany kwalifikacji użytków rolnych niektóre wsie należące do gminy mogą znaleźć się w innym okręgu podatkowym niż dla niej określony, nie może to jednak doprowadzić do zmniejszenia liczby hektarów przeliczeniowych w tej gminie o więcej niż $1,5 \%$.

Jak wcześniej zaznaczono, rada gminy uprawniona jest do uchwalenia dodatkowych zwolnień podatkowych o charakterze przedmiotowym, jak również przedmiotowych ulg wykraczających poza określone w ustawie o podatku rolnym. W ramach jej władztwa podatkowego mieszczą się także decyzje o zarządzaniu poboru podatku w drodze inkasa, o wyznaczaniu inkasentów i o określaniu wysokości wynagrodzenia za inkaso (Kornberger-Sokołowska, 2016, s. 194).

\section{Stawki podatkowe oraz finansowe konsekwencje zastosowania wtadztwa podatkowego przez gminy}

W okresie objętym analizą ceny skupu żyta, na podstawie której wyznaczane są stawki podatku rolnego, ulegały znacznym i różnokierunkowym zmianom. Na taką sytuację wpływał szereg czynników absolutnie niezależnych od władz samorządowych, a oddziałujących na sytuację finansową gmin będących beneficjentami podatku rolnego. Do tych czynników należały: urodzaj lub ograniczenie plonów na skutek działania czynników atmosferycznych, popyt na 
żyto, zmieniający się m.in. w zależności od upodobań konsumentów i mody, kształtowanie się popytu, podaży oraz cen ziarna na rynkach zagranicznych itp. Poziom obciążeń podatkiem rolnym w latach 2003-2018 ulegał wyraźnym fluktuacjom, które doprowadziły do zmian w sposobie ustalania stawki podatku rolnego. Największą zmianę in minus gminy odczuły w 2006 i 2010 r., natomiast największy wzrost - w 2008 i 2012 r. Warto podkreślić, że od 2013 r. średnia cen skupu żyta wykazuje tendencję spadkową i choć wskaźnik wzrostu cen w tym czasie był bardzo niewielki lub wprost ujemny, to sytuacja ta niekorzystnie odbijała się na sytuacji finansowej gmin. Wysokość średniej ceny skupu żyta oraz wielkość utraconych przez gminy dochodów na skutek prowadzonej polityki podatkowej $\mathrm{w}$ tym okresie przedstawiono $\mathrm{w}$ tabeli 1 .

Tabele 1. Średnia cena skupu żyta i dochody utracone przez gminy na skutek prowadzenia polityki podatkowej

\begin{tabular}{|l|r|r|r|r|r|r|}
\hline \multirow{2}{*}{ Rok } & $\begin{array}{c}\text { Średnia } \\
\text { cena skupu } \\
\text { żyta }\end{array}$ & $\begin{array}{c}\text { Tempo } \\
\text { zmian } \\
\text { średniej } \\
\text { ceny skupu } \\
\text { żyta }\end{array}$ & Inflacja & $\begin{array}{c}\text { Wielkośćc } \\
\text { utraconych } \\
\text { dochodów }\end{array}$ & $\begin{array}{c}\text { Tempo } \\
\text { zmian } \\
\text { utraconych } \\
\text { dochodów }\end{array}$ & $\begin{array}{c}\text { Udział } \\
\text { utraconych } \\
\text { dochodów } \\
\text { w dochodach } \\
\text { ogółem }\end{array}$ \\
\cline { 2 - 8 } & \multicolumn{1}{|c|}{ z1 } & \multicolumn{2}{|c|}{$\%$} & mln zł & \multicolumn{2}{|c|}{$\%$} \\
\hline 2003 & 33,45 & \multicolumn{2}{|c|}{ x } & 100,80 & 133,3 & \multicolumn{2}{c|}{$\times$} & 0,37 \\
\hline 2005 & 34,57 & 3,35 & 103,50 & 134,6 & 0,94 & 0,33 \\
\hline 2006 & 27,88 & $-25,99$ & 101,00 & 70,9 & $-60,15$ & 0,39 \\
\hline 2007 & 35,52 & 27,40 & 102,50 & 158,5 & 123,43 & 0,28 \\
\hline 2008 & 58,29 & 64,10 & 104,20 & 531,1 & 235,19 & 0,85 \\
\hline 2009 & 55,8 & $-4,27$ & 103,50 & 458,3 & $-13,70$ & 0,71 \\
\hline 2010 & 34,1 & $-38,89$ & 102,60 & 62,5 & $-86,36$ & 0,09 \\
\hline 2011 & 37,64 & 10,38 & 104,30 & 93,5 & 49,58 & 0,12 \\
\hline 2012 & 74,18 & 97,08 & 103,70 & 712,2 & 661,52 & 0,91 \\
\hline 2013 & 75,86 & 2,26 & 100,90 & 667,9 & $-6,22$ & 0,83 \\
\hline 2014 & 69,28 & $-8,67$ & 100,00 & 481,9 & $-27,86$ & 0,57 \\
\hline 2015 & 61,37 & $-11,42$ & 99,10 & 308,5 & $-35,98$ & 0,16 \\
\hline 2016 & 53,75 & $-12,42$ & 99,40 & 149,9 & $-51,41$ & 0,09 \\
\hline 2017 & 52,44 & $-2,44$ & 102,00 & 125,8 & $-16,08$ & 0,08 \\
\hline 2018 & 52,49 & 0,10 & 101,60 & 123,4 & $-1,92$ & 0,08 \\
\hline
\end{tabular}

(Źródło: opracowanie własne na podstawie: KR RIO (2004-2019), Sprawozdanie z działalności regionalnych izb obrachunkowych i wykonania budżetu przez jednostki samorzadu terytorialnego za lata 2003-2018, pozyskano z rio.gov.pl i stat.gov.pl [dostęp: 15.11.2019]). 
Analiza skutków finansowych polityki podatkowej gmin pozwala zauważyć, że w kolejnych latach wielkości dochodów utraconych przez gminy na skutek jej prowadzenia znacznie się różniły i były skorelowane z wysokością ceny skupu żyta. W okresach, gdy ulegały one wyraźnej redukcji, co nastąpiło w latach 2006, 2010 i 2011, czy też utrwalonego już trendu spadkowego ceny żyta, odczuwalnego od 2014 r., gminy wykazywały mniejszą skłonność do obniżania stawek tego podatku ${ }^{2}$ - a więc uwzględniały to, że był on okresowo stosunkowo niewielkim obciążeniem dla podatników, a równocześnie - że strumienie dochodów budżetowych słabły (Śmiechowicz \& Kozak, 2016, s. 474). Co więcej, ubytki dochodów z podatku rolnego podlegały wahaniom związanym również z kształtowaniem się innych kategorii budżetowych, głównie z występowaniem dużego deficytu budżetowego i rosnącego poziomu zadłużenia. Nie oznacza to jednak, że w latach jego wzrostu gminy wykazywały wyraźnie mniejszą skłonność do rezygnacji z dochodów podatkowych. Od 2015 r. udział utraconych dochodów na skutek obniżania stawek podatków lokalnych, stosowania ulg i zwolnień podatkowych przez organy gminy jest wprost marginalny i głównie, tj. w ok. $75-80 \%$, spowodowany redukowaniem stawek podatku rolnego ${ }^{3}$. Zrozumiały jest fakt, że największa utrata dochodów dotyczy gmin wiejskich (ok. 68\%), a w wyraźnie mniejszym stopniu - ok. 31\% - gmin miejsko-wiejskich. Natomiast udział gmin miejskich w ogólnych ubytkach dochodów gmin na skutek prowadzenia polityki podatkowej wynosił mniej niż 1\% (Przygodzka, 2014, s. 338). W 2013 r. spośród 2479 polskich gmin ponad 77\% zdecydowało się obniżyć średnią cenę skupu żyta, z czego 1332 miało status gmin wiejskich (85\% ogółu tego typu jednostek), 501 gmin miejsko-wiejskich (83\% ogółu) i 86 gmin miejskich (28\% ogółu) (Ministerstwo Finansów, 2014, s. 44).

\section{Analiza znaczenia podatku rolnego w tworzeniu dochodów gmin}

Podatek rolny nie należy do wydajnych fiskalnie dochodów gmin; co więcej, poziom wpływów z jego tytułu wykazuje w poszczególnych latach silne fluktu-

2 W latach 2008 i 2009, gdy średnia cena skupu żyta była relatywnie wysoka, na jej obniżkę zdecydowało się ponad 70\% gmin, a w 2010 r., gdy była ona bardzo niska - właściwe uchwały podjęło ok. 25\% gmin. Wzrost średniej ceny skupu żyta w 2011 r. skutkował tym, że na obniżkę ceny zdecydowało się już blisko 40\% gmin. Zob. Melis, 2015, s. 30.

3 Na podstawie: KR RIO (2018-2019), Sprawozdanie $z$ działalności regionalnych izb obrachunkowych $i$ wykonania budżetu przez jednostki samorządu terytorialnego z 2017 i 2018 roku, pozyskano z www.rio.gov.pl (10.10.2019). 
acje, przyczyniające się do destabilizowania dochodów gmin. Rola tej daniny w tworzeniu budżetów gmin wyraźnie zmniejszyła się w okresie objętym badaniem i tę tendencję uznać można za stałą. W $2003 \mathrm{r}$. dochody z podatku rolnego stanowiły 2,4\% dochodów ogółem i 5,4\% dochodów własnych. Najmniejszy udział w tworzeniu budżetów gmin miał on w 2010 r. tj. 1,4\% i pod koniec okresu badawczego, czyli w latach 2017-2018, bo tylko 1,3\% oraz 1,2\%. Znaczenie fiskalne podatku rolnego tj. wielkość wpływów oraz ich udział w dochodach ogółem gmin zaprezentowano w tabeli 2.

Tabela 2. Dochody z podatku rolnego i ich udział w tworzeniu dochodów gmin w latach 2002-2018

\begin{tabular}{|c|c|c|c|c|c|c|c|c|}
\hline \multirow{3}{*}{$\begin{array}{l}\text { Wyszczególnienie } \\
\text { ogółem }\end{array}$} & 2003 & 2004 & 2005 & 2006 & 2007 & 2008 & 2009 & 2010 \\
\hline & \multicolumn{8}{|c|}{ Dochody w mln zł } \\
\hline & 36046 & 40309 & 45813 & 51724 & 57003 & 62318 & 64882 & 72311 \\
\hline własne & 16112 & 18732 & 20558 & 22684 & 26535 & 30695 & 30022 & 32264 \\
\hline \multirow[t]{2}{*}{ z podatku rolnego } & 863 & 906 & 950 & 796 & 915 & 1204 & 1215 & 974 \\
\hline & \multicolumn{8}{|c|}{ Tempo zmian dochodów w $\%$} \\
\hline ogółem & $\mathrm{x}$ & 11,82 & 13,66 & 12,90 & 10,21 & 9,32 & 4,11 & 11,45 \\
\hline własne & $\mathrm{x}$ & 16,26 & 9,75 & 10,34 & 16,98 & 15,67 & $-2,19$ & 7,4 \\
\hline \multirow[t]{2}{*}{ z podatku rolnego } & $\mathrm{x}$ & 4,92 & 4,84 & $-16,22$ & 15,03 & 31,49 & 0,97 & $-19,84$ \\
\hline & \multicolumn{8}{|c|}{ Udział podatku rolnego w $\%$} \\
\hline w dochodach ogółem & 2,40 & 2,25 & 2,07 & 1,54 & 1,61 & 1,93 & 1,87 & 1,3 \\
\hline $\begin{array}{l}\text { w dochodach } \\
\text { własnych }\end{array}$ & 5,36 & 4,84 & 4,62 & 3,51 & 3,45 & 3,92 & 4,05 & 3,0 \\
\hline \multicolumn{9}{|c|}{$\mathrm{KR}$} \\
\hline \multirow{3}{*}{$\begin{array}{l}\text { Wyszczególnienie } \\
\text { ogółem }\end{array}$} & 2011 & 2012 & 2013 & 2014 & 2015 & 2016 & 2017 & 2018 \\
\hline & \multicolumn{8}{|c|}{ Dochody w mln zł } \\
\hline & 75831 & 78407 & 80043 & 84549 & 87667 & 101795 & 111189 & 121426 \\
\hline własne & 34490 & 36523 & 38546 & 41711 & 43573 & 45135 & 48076 & 52530 \\
\hline \multirow[t]{2}{*}{ z podatku rolnego } & 1046 & 1517 & 1635 & 1626 & 1569 & 1491 & 1464 & 146 \\
\hline & \multicolumn{8}{|c|}{ Tempo zmian dochodów w \% } \\
\hline ogółem & 4,87 & 3,40 & 2,09 & 5,63 & 3,69 & 16,12 & 9,23 & 9,21 \\
\hline własne & 6,90 & 5,89 & 5,54 & 8,21 & 4,47 & 3,58 & 6,52 & 9,26 \\
\hline \multirow[t]{2}{*}{ z podatku rolnego } & 7,37 & 45,03 & 7,78 & $-0,54$ & $-3,51$ & $-4,94$ & $-1,86$ & $-0,22$ \\
\hline & \multicolumn{8}{|c|}{ Udział podatku rolnego w $\%$} \\
\hline w dochodach ogółem & 1,38 & 1,93 & 2,04 & 1,92 & 1,79 & 1,47 & 1,32 & 1,20 \\
\hline $\begin{array}{l}\text { w dochodach } \\
\text { własnych }\end{array}$ & 3,03 & 4,15 & 4,24 & 3,90 & 3,60 & 3,30 & 3,04 & 2,7 \\
\hline
\end{tabular}


Porównując wielkość dochodów zgromadzonych z tytułu podatku rolnego w latach 2003 i 2018, okazuje się, że były one większe tylko o 69\%, podczas gdy dochody ogółem - o 237\%. Najbardziej odczuwalny spadek dochodów z podatku rolnego gminy odnotowały w latach 2006 i 2010: odpowiednio o ponad $16 \%$ i prawie 20\%. Z kolei w 2007 r., 2008 r., a zwłaszcza w 2012 r. wielkość dochodów z tego źródła wzrosła najwięcej w stosunku do roku poprzedniego. Zmiana zasad ustalania wysokości stawki podatku rolnego od 2011 r. pozwoliła gminom na pewne ustabilizowanie wpływów z podatku rolnego - wahania wielkości dochodów gromadzonych z jego tytułu w kolejnych latach zmniejszyły się. Zjawisku temu nie towarzyszyło jednak zwiększenie udziału podatku rolnego w dochodach budżetowych gmin lub choćby jego utrzymanie na stałym poziomie. Po wzroście w latach 2012 i 2013 rola podatku rolnego jako źródła dochodów budżetowych gmin ulegała sukcesywnej redukcji przez pięć kolejnych lat.

\section{Zróżnicowanie wydajności fiskalnej podatku rolnego i skutków polityki podatkowej w gminach województwa lubelskiego}

Gminy w Polsce są bardzo liczną i niejednolitą grupą jednostek samorządu terytorialnego, co powoduje, że rola poszczególnych źródeł w tworzeniu ich budżetów jest odmienna. Analizę dotyczącą wydajności fiskalnej podatku rolnego warto więc pogłębić. Objęte nią będą jednostki położone w województwie lubelskim, gdzie rolnictwo wciąż pozostaje ważną branżą gospodarki. Za podstawę analizy posłużą dane zawarte w sprawozdaniach $\mathrm{Rb}-27 \mathrm{~S}$ dostępnych na stronie internetowej RIO w Lublinie.

Na terenie województwa lubelskiego funkcjonuje obecnie 209 podstawowych jednostek samorządu terytorialnego, z czego 165 to gminy wiejskie, 16 - miejskie, a 28 ma charakter miejsko-wiejski. W grupie gmin wiejskich znajdują się jednostki liczące od 1634 (gmina Podedwórze składająca się z 13 sołectw) do 23130 mieszkańców (gmina Zamość tworzona przez 35 sołectw). Przeciętna liczna mieszkańców w gminach wiejskich województwa lubelskiego wynosiła W 2018 r. 5991 osób, a mediana - 5157 osób. W gminach tych w 2018 r. dochód z podatku rolnego per capita wahał się w granicach od 24,5 zł w Biłgoraju do $438 \mathrm{zł} \mathrm{w}$ Dołhobyczowie, rozpiętość była więc znacząca. Średni dochód z podatku rolnego na mieszkańca gminy wiejskiej w lubelskim wynosił 143 zł, a wartość środkowa - 115 zł. Bardzo zróżnicowany był też udział podatku rolnego w tworzeniu dochodów gmin wiejskich i mieścił się w granicach od o,55\% w Biłgoraju 
do 10,32\% w Ulhówku. Dość duże znaczenie podatek rolny ma w tworzeniu budżetów gmin Dołhobyczów, Hrubieszów, Mircze, Telatyn czy Uhanie, gdzie jego dział w dochodach ogółem mieścił się w granicach 9,64\%-8,18\%. W kolejnych 13 gminach podatek rolny stanowił więcej niż 6\% i mniej niż 8\% dochodów ogółem, a w przypadku następnych 18 - w granicach od 4 do $6 \%$. Przeciętnie w gminach wiejskich województwa lubelskiego podatek rolny tworzył 3,2\% dochodów budżetowych; poniżej średniej udział ten kształtował się w 106 jednostkach. $\mathrm{W}$ efekcie stosowania preferencji podatkowych gminy wiejskie w lubelskim utraciły $31,1 \mathrm{mln}$ zł w związku z obniżeniem ceny skupu żyta, 146 tys. zł - na skutek zastosowania ulg i zwolnień pozaustawowych i 534 tys. zł w efekcie wydawania decyzji przez organ podatkowy na podstawie Ordynacji podatkowej, co łącznie stanowiło 0,69\% dochodów ogółem. W 57 gminach nie odnotowano ubytku z powodu obniżenia ceny skupu żyta, 20 nie przyznało ulg i zwolnień.

Liczba gmin miejskich na terenie województwa lubelskiego wynosi 16. Najmniejszą z nich jest Stoczek Łukowski zamieszkiwany przez 2536 osób, a największą Puławy, w których żyją 47774 osoby. Przeciętna liczba mieszkańców małego miasta w województwie lubelskim wynosiła w 2018 r. 20635 osób. W gminach miejskich wpływy z podatku rolnego są z oczywistych powodów niewielkie, co rekompensują z kolei większe dochody z tytułu podatku od nieruchomości. We Włodawie dochód na 1 mieszkańca z podatku rolnego wyniósł zaledwie 1,22 zł, a w Biłgoraju tylko 1,89. Z kolei w Krasnymstawie i Stoczku Łukowskim, gdzie był on największy, kształtował się na poziomie 24,65 i 24,28 zł. Przeciętnie dochody z podatku rolnego gmin miejskich wyniosły 9,1 zl, ale dochody poniżej tej kwoty odnotowało 10 jednostek. Konsekwencją niewielkiej wydajności fiskalnej podatku rolnego $\mathrm{w}$ gminach miejskich był śladowy wprost udział podatku rolnego w dochodach ogółem, mieszczący się w granicach 0,03\% do 0,13\%. Na skutek przyjmowania obniżonej stawki podatku rolnego, na co zdecydowało się osiem jednostek, gminy miejskie utraciły łącznie niespełna 203 tys. zł, z czego najwięcej Kraśnik (prawie 59 tys. zł). W rezultacie zastosowania ulg i zwolnień pozaustawowych uszczuplenia dochodów doznała jedna gmina - Łuków, w kwocie 1495 zł. Natomiast suma umorzonych zaległości podatkowych przez gminy miejskie w województwie lubelskim wyniosła 2263 zł. Łącznie utracone przez gminy miejskie w lubelskim dochody stanowiły o,01\% ogółu dochodów gmin.

W gminach miejsko-wiejskich, które również są zróżnicowane pod względem zamieszkującej je populacji (najmniejsza z nich, Ostrów Lubelski, liczy 5228 osób, a największa Łęczna - 23 398), dochody z podatku rolnego były znacznie wyższe w przeliczeniu na mieszkańca niż w gminach miejskich, i wynosiły od 11,57 zł w Janowie Lubelskim do 285,73 zł w Lubyczy Królewskiej. Przeciętne 
dochody z podatku rolnego per capita wyniosły 106,37 zl, a dochody powyżej średniej zgromadziło 10 jednostek. Odsetek dochodów, jakie poszczególne gminy miejsko-wiejskie uzyskały z tytułu podatku rolnego był bardzo zróżnicowany. W pięciu gminach miejsko-wiejskich kształtował się poniżej 1\%, a najniższą wartość, tj. 0,29\%, przyjął w Janowie Lubelskim. Najwyższy poziom, przekraczający 6\%, osiągnął w dwóch gminach: w Łaszczowie i Lubyczy Królewskiej (odpowiednio 6,39\% i 6,45\%). Finansowe efekty redukcji ceny skupu żyta były w gminach miejsko-wiejskich znacznie bardziej odczuwalne niż w gminach miejskich. Omawiana grupa jednostek utraciła $\mathrm{z}$ tego tytułu w $2018 \mathrm{r}$. łącznie 4,62 mln zł: najwięcej Urzędów - 619 tys. zł - oraz Bychawa - 615 tys. zł. Spośród 28 gmin miejsko-wiejskich w lubelskim tylko dwie nie zdecydowały się na przyjęcie obniżonej stawki podatku. Z powodu udzielania ulg i zwolnień dochody gmin miejsko-wiejskich były o 36,7 tys. zł niższe niż potencjalne, przy czym pięć gmin nie udzieliło tego rodzaju preferencji, a najdotkliwsze konsekwencje finansowe dotknęły Józefów i Łaszczów, które utraciły 6623 zł oraz $5865 \mathrm{zł}$. W efekcie wydania decyzji o umorzeniu zaległości podatkowych, odroczeniu terminu płatności, rozłożeniu na raty, zwolnieniu z obowiązku pobrania lub ograniczeniu poboru możliwe do uzyskania dochody budżetowe gmin miejsko-wiejskich uległy zmniejszeniu o 114 tys. zł. Potencjalnie dochody ogółem gmin miejsko-wiejskich byłyby o 0,4\% wyższe, gdyby zrezygnowały one z polityki podatkowej w zakresie podatku rolnego.

\section{Podsumowanie}

Przeprowadzone w tym opracowaniu badania pozwalają na sformułowanie kilku konkluzji i zweryfikowanie postawionych hipotez badawczych. Podatek rolny jest, ogólnie rzecz ujmując, mało wydajną fiskalnie daniną, co wynika z jego konstrukcji coraz bardziej nieprzystającej do stosunków społeczno-gospodarczych w Polsce. Jego istotną zaletą, z punktu widzenia gmin będących beneficjentami podatku rolnego, jest możliwość oddziaływania w ograniczonym zakresie na niektóre elementy zmienne podatku, a więc stosowania władztwa podatkowego. Biorąc jednak pod uwagę słabnący udział tej daniny w tworzeniu dochodów gmin, pomimo stopniowego ograniczania stosowanych przez nie preferencji podatkowych, stwierdzić można, że podatek rolny w coraz mniejszym stopniu wpływa na samodzielność gmin. Wyniki przeprowadzonych badań nie pozwoliły na potwierdzenie pierwszej hipotezy przyjętej w opracowaniu. Faktem jest spadający udział podatku rolnego w dochodach ogółem gmin, nie jest to jednak spowodo- 
wane ich łagodną polityką podatkową. W badanym okresie uwidoczniło się, że gminy, po pierwsze, dostosowują swoje decyzje do uwarunkowań zewnętrznych (są więc elastyczne), a po drugie - ograniczają stopniowo zakres udzielanych preferencji podatkowych, co znajduje odzwierciedlenie w coraz mniejszym udziale utraconych dochodów z podatku rolnego w dochodach ogółem. Druga hipoteza również nie została zweryfikowana pozytywnie. Wydajność fiskalna podatku rolnego jest mocno zróżnicowana, zarówno między poszczególnymi typami gmin, jak i w ramach jednego typu. Niewątpliwie podatek rolny nie jest ważną daniną dla gmin miejskich, ale dla części gmin miejsko-wiejskich i wiejskich również nie stanowi on wydajnego źródła zasilania finansowego. Niektóre gminy miejsko-wiejskie czerpią dość wysokie dochody z podatku rolnego i w związku z tym jego udział w dochodach ogółem tego rodzaju jednostek jest zbliżony do udziału podatku rolnego w budżetach gmin wiejskich. W ramach każdego typu gmin, zwłaszcza w grupie gmin wiejskich, występują znaczące odchylenia od średniego udziału podatku rolnego w dochodach ogółem, typowego dla danej kategorii gmin.

\section{Bibliografia}

Dziemianowicz, R. (2007). Ocena polskich rozwiązań w zakresie opodatkowania rolnictwa na tle systemów obowiązujących w wybranych krajach Unii Europejskiej. Zeszyty Naukowe SGGW w Warszawie. Problemy Rolnictwa Światowego, 2(17), 184-194.

Dziemianowicz, R. I. (2007). Efektywność opodatkowania rolnictwa. Białystok, Polska: Uniwersytet w Białymstoku.

Etel, L. (2003). Podatek od nieruchomości, rolny i leśny, Komentarz. Warszawa, Polska: Wydawnictwo C. H. Beck.

Etel, L., Presnarowicz, S., \& Dudar, G. (2008). Podatki i opłaty lokalne. Podatek rolny. Podatek leśny. Warszawa, Polska: ABC a Wolters Kluwer Business.

Eurostat (2013). Taxation Trends in the European Union. Pozyskano z https://ec.europa. eu/ (dostęp: 10.10.2019).

Felis, P. (2015). Uwarunkowania funkcji fiskalnej podatku rolnego. Roczniki Naukowe Ekonomii Rolnictwa i Rozwoju Obszarów Wiejskich, 2(2), 23-36.

Filipiak, B. Z. (2015). Polityka podatkowa gmin czy realizacja władztwa podatkowego? Finanse, Rynki Finansowe, Ubezpieczenia, 76(1), 221-230. doi: 10.18276/ frfu.2015.76/1-19.

Filipiak, B. Z. (2016). Skutki udzielania ulg, umorzeń i zwolnień przez organy podatkowe gmin. Finanse, Rynki Finansowe, Ubezpieczenia, 5(83), 177-187. doi: 10.18276/ frfu.2016.5.83/1-16. 
GUS (n.d.). Bank Danych Makroekonomicznych. Bilans Płatniczy. Pozyskano z stat.gov. $\mathrm{pl} /$ wskaźniki-makroekonomiczne (dostęp: 10.11.2019).

Kisiel, R., \& Idzikowska, K. (2014). System opodatkowania rolnictwa w Polsce oraz w wybranych krajach Unii Europejskiej. Zeszyty Naukowe SGGW. Polityki Europejskie, Finanse i Marketing, 12(61), 64-78.

Kornberger-Sokołowska, E. (2016). Dylematy reformy systemu podatkowego w Polsce. Warszawa, Polska: Centrum Studiów Samorządu Terytorialnego i Rozwoju Lokalnego UW.

Kowalski, A. \& Wigiera, M. (red.) (2012). Zmiany systemu podatkowego w rolnictwie. Konkurencyjność polskiej gospodarki żywnościowej w warunkach globalizacji i integracji europejskiej. Warszawa, Polska: Instytut Ekonomiki Rolnictwa i Gospodarki Żywnościowej. Państwowy Instytut Badawczy.

KR RIO (2004-2019). Sprawozdania $z$ działalności regionalnych izb obrachunkowych i wykonania budżetu przez jednostki samorzadu terytorialnego za lata 2003-2018. Pozyskano z www.rio.gov.pl (dostęp: 10.10.2019).

Kulicki, J. (2010). Zakres władztwa podatkowego w obecnym systemie prawnym w Polsce. Biuro Analiz Sejmowych BAS, 16(41), 1-25.

Ministerstwo Finansów (2012). Preferencje podatkowe w Polsce. Nr3. Pozyskano z https:// www.podatki.gov.pl/abc-podatkow/podatki-w-polsce/preferencje-podatkowe-w-polsce/.

Ministerstwo Finansów (2014). Preferencje podatkowe w Polsce. Nr 5. Pozyskano z https:// www.podatki.gov.pl/abc-podatkow/podatki-w-polsce/preferencje-podatkowe-w-polsce/ (dostęp: 10.10.2019).

OECD (2005). Taxation and social Security in Agriculture. Pozyskano z https://www. oecd-ilibrary.org/agriculture-and-food/taxation-and-social-security-in-agriculture_9789264013650-en (dostęp: 10.10.2019).

Ofiarski, Z. (2016). System (zbiór) podatków samorządowych - wstępne propozycje uporządkowania. Annales Universitatis Mariae Curie-Skłodowska Lublin - Polonia Sectio $H, L(1), 265-274$.

Pomorska, A. (2016). Potrzeba i kierunki reformy podatków dochodowych w Polsce. Lublin, Polska: Wydawnictwo KUL.

Przygodzka, R. (2014). Władztwo podatkowe a stabilność finansowa gmin. Nierówności Społeczne a Wzrost Gospodarczy, 40, 334-343.

Śmiechowicz, J., \& Kozak, P. (2016). Diagnoza skutków polityki podatkowej gmin w Polsce w latach 2003-2015. Prace Naukowe Uniwersytetu Ekonomicznego we Wrocławiu, 451, 468-478.

van der Veen, H. B., van der Meulen, H. A. B., van Bommel, K. H. M., \& Doorneweert, R. B. (2007). Exploring agricultural taxation in Europe. Haga, Holandia: LEI. 
Wójtowicz, K. (2016). Propozycje zmian w systemie opodatkowania dochodów rolniczych w Polsce. Studia Ekonomiczne. Zeszyty Naukowe Uniwersytetu Ekonomicznego w Katowicach, 294, 212-224.

\section{Akty prawne}

Europejska Karta Samorządu Lokalnego sporządzona w Strasburgu dnia 15 października 1985 r., Dz.U. z 1994 r. |Nr 124, poz. 607, sprost. Dz.U. z 2006 r. Nr 154, poz. 1107. Konstytucja Rzeczpospolitej Polskiej z dn. 2 kwietnia 1997 r., Dz.U. Nr 78, poz. 483 z późn. zm.

Ustawa z dn. 15 listopada 1994 r. o podatku rolnym, tj. Dz.U. z 2019 r., poz. 1256 z późn. zm. Ustawa z dn. 13 listopada 2003 r. o dochodach jednostek samorządu terytorialnego, tj. Dz.U. z 2018 r. poz. 1530 z późn. zm.

\section{Streszczenie}

Celem ogólnym opracowania jest zbadanie ewolucji roli podatku rolnego w tworzeniu dochodów gmin i prowadzonej przez nie polityki podatkowej, a także określenie jej konsekwencji budżetowych. Za cel szczegółowy przyjęto analizę zróżnicowania wydajności fiskalnej i wykorzystania władztwa podatkowego przez różne typy gmin w województwie lubelskim. W badaniach obejmujących lata 2003-2018 oparto się na danych zbiorczych, udostępnianych w bazie Głównego Urzędu Statystycznego, oraz na danych zawartych w sprawozdaniach Rb-27S pobranych ze strony internetowej Regionalnej Izby Obrachunkowej w Lublinie. Przygotowanie artykułu wymagało zastosowania metody analizy porównawczej, prostej analizy statystycznej danych oraz metody dedukcyjnej. Główny wniosek płynący z przeprowadzonych badań brzmi, że podatek rolny jest coraz mniej wydajnym fiskalnie źródłem dochodów gmin, a jego rola w tworzeniu ich budżetów jest bardzo mocno zróżnicowana nie tylko między gminami miejskimi a wiejskimi i miejsko-wiejskimi, ale również w ramach jednego rodzaju gmin.

SŁoWA KLUCzowE: podatek rolny, władztwo podatkowe gmin, wydajność fiskalna podatku rolnego, skutki polityki podatkowej gmin

\section{Summary}

The general objective of the study is to examine the evolution of the role of agricultural tax in creating municipalities' income and their tax policy, as well as determining its budgetary consequences. The analysis of the diversification of fiscal efficiency and the use of tax authority by various types of communes in the Lubelskie Voivodeship has been adopted as a specific objective. The research covering the years 2003-2018 was based on aggregate data available in the database of the Central Statistical Office and data contained in $\mathrm{Rb}-27 \mathrm{~S}$ reports downloaded from the website of the Regional Accounting Chamber in Lublin. Preparation of the article required the use of comparative analysis method, simple statistical data analysis and deductive method. The main conclusion of the study 
is that the agricultural tax is a less and less efficient source of revenue for municipalities, and its role in creating their budgets is very diverse not only between urban and rural and urban-rural municipalities but also within one type of municipalities.

KEYWORDS: agricultural tax, tax authority of communes, fiscal efficiency of agricultural tax, consequences of municipalities' tax policy

Nota o autorze

Dr Joanna Śmiechowicz - UMCS w Lublinie, Wydział Ekonomiczny, Katedra Finansów Publicznych, główne dziedziny działalności naukowej: finanse publiczne, w tym: finanse samorządu terytorialnego, partnerstwo publiczno-prywatne, e-mail: j.smiechowicz@02.pl, ORCID: 0000-0003-2101-4068. 